\title{
A Bite Block- Newer Technique
}

\author{
Amit Sidana ${ }^{1 *}$, Pooja $\mathrm{T}^{2}$, Ragni $\mathrm{T}^{3}$ and Manu $\mathrm{K}^{4}$ \\ ${ }^{1}$ Senior Lecturer, Institute- Maharaja Ganga Singh Dental College, India \\ ${ }^{2}$ Kothiwal Dental College, India
}

${ }^{3}$ Professor, Head of Department, Institute-Saraswati Dental College, India

${ }^{4}$ Department of Orthodontics, Maharaja Ganga Singh Dental College, India

Submission: September 06, 2016; Published: December 13, 2017

*Corresponding author: Amit Sidana, Senior Lecturer, Maharaja Ganga Singh Dental College, Sri Ganganagar, Rajasthan, India, Tel: 8181854254; Email: dramiortho@gmail.com

\begin{abstract}
Biteplanes can be used in Class I and Class II, division 1 or 2 cases for the correction of deep bite with moderate overjet. A deep bite must be opened before brackets can be bonded in the mandibular arch. The most common devices used to open the bite are removable anterior or posterior biteplanes and glass ionomer cement (GIC). Removable posterior biteplane is part-time, may be lost or broken and sometime patient may swallow it. GIC bite blocks can cause discomfort during chewing because of the single points of contact on each side. On removal of fixed bite blocks,adhesive remnants inadvertently left over on the tooth structure requires meticulous clean up and equilibration of occlusal tooth surface morphology [1]. Many of these problems can be overcome by using a fixed biteplane without cementation which is easy to remove after correction.
\end{abstract}

Keywords: Bite block; Cementation

\section{Introduction}

Biteplanes can be used in Class I and Class II, division 1 and 2 cases for the correction of deep bite with moderate overjet. A deep bite must be opened before brackets can be bonded in the mandibular arch. The most common devices used to open the bite are removable anterior or posterior biteplanes and glass ionomer cement (GIC). Removable posterior bite plate is part-time, may be lost or broken and sometime patient may swallow it. GIC bite blocks can cause discomfort during chewing because of the single points of contact on each side. Many of these problems can be overcome by using a fixed biteplane without cementation which is easy to remove after correction.

\section{Procedure}

1. Place the band on the teeth 36 and 46 and take alginate impression. Keep in mind that in impression, band is placed in proper position.

2. Pour the impression in Plaster of Paris, after setting of pop remove the cast.

3. Bend the lingual arch $(0.9 \mathrm{~mm}$ wire $)$ and adapt it lingually in the mandible (Figure 1a).

4. Occlusal component, adapt the wire $(0.7 \mathrm{~mm})$ on occlusal surface start from middle of second molar and move mesially up to interdental space between first and second premolar than give vertical bend downward adapt between embrasure area and end rest on lingual arch (Figure 1).

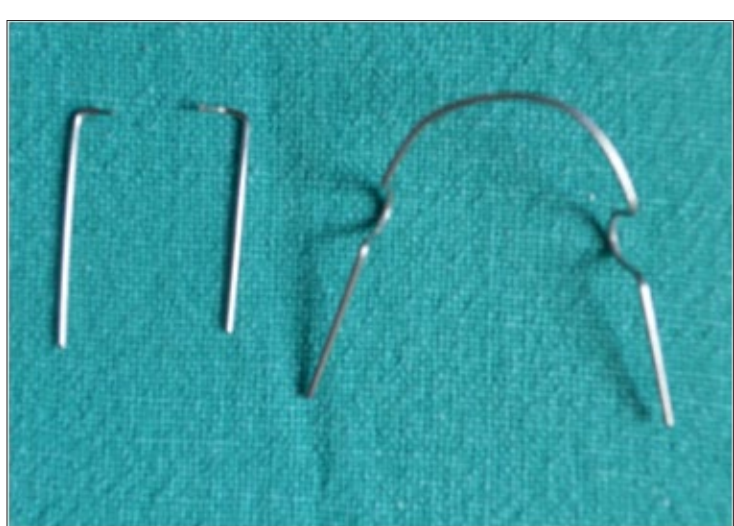

Figure 1: The lingual arch $(0.9 \mathrm{~mm}$ wire $)$, ). Occlusal component $(0.7 \mathrm{~mm}$ wire $)$.

5. Solder the lingual arch on the band and the occlusal component on lingual arch (Figure 2a,2b).

6. Apply separating media on occlusal surface of posterior teeth and form acrylic bite block on occlusal component (Figure 3a,3b).

7. Remove it from cast and cement the band on their respective teeth (Figure $4 a, 4 b$ ).

8. After desired correction is achieved, cut the occlusal component near the solder point with the help of cutter and remove the block. 


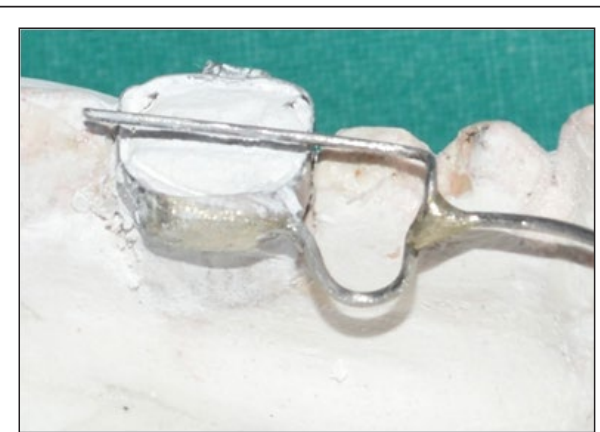

Figure 2a: Lateral View: Solder the lingual arch on the band and the occlusal component on lingual arch.

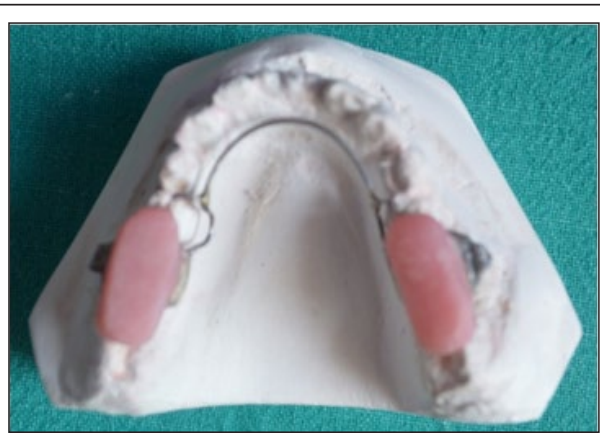

Figure 3a: Occlusal View: Solder the lingual arch on the band and the occlusal component on lingual arch.

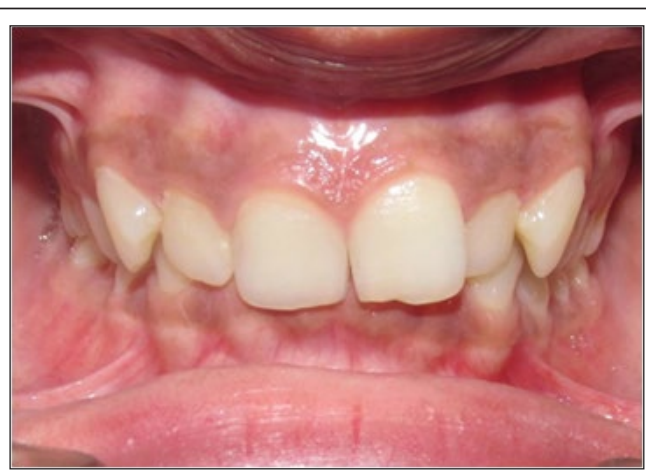

Figure 4a : Without Bite Block.

\section{Advantages}

1. It does not need patient cooperation.

2. It can be used full-time.

3. It does not require any bonding material so there is no damage to enamel.

4. It is hygienic.

5. It can be easily removal

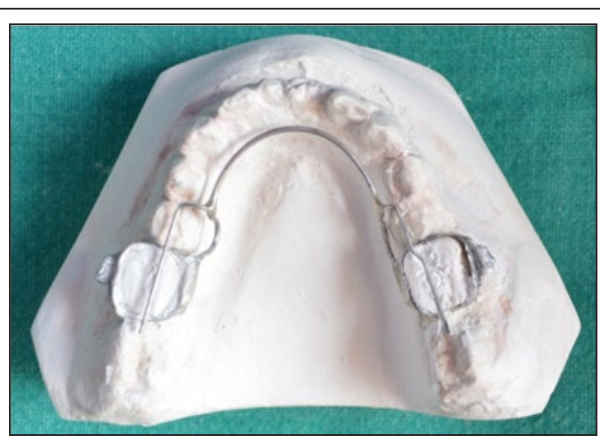

Figure 2b: : Occlusal View: Solder the lingual arch on the band and the occlusal component on lingual arch.

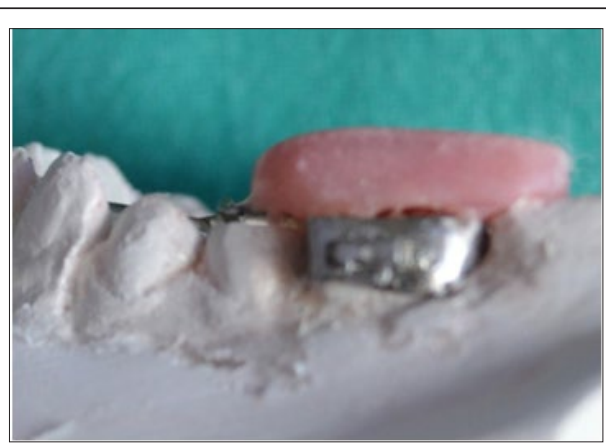

Figure 3b : Lateral View: Acrylic bite block on occlusal component.

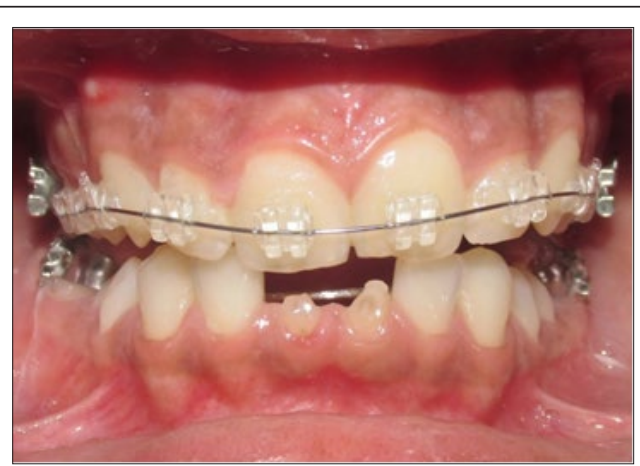

Figure 4b : With Bite Block.

\section{Conclusion}

This particular bite block can be concurrently used in combination with fixed appliance mechanotherapy. It is easy to fabricate and remove just cutting the wire from joint intraorally and leaves behind no adhesive remanants and protect enamel from useless grinding.

\section{Reference}

1. Maheshwara MV (2016) Hygienic bite blocks. APOS 6(3): 175-176. 
his work is licensed under Creative Commons Attribution 4.0 Licens

DOI: 10.19080/ADOH.2017.07.555702
Your next submission with Juniper Publishers will reach you the below assets

- Quality Editorial service

- Swift Peer Review

- Reprints availability

- E-prints Service

- Manuscript Podcast for convenient understanding

- Global attainment for your research

- Manuscript accessibility in different formats ( Pdf, E-pub, Full Text, Audio)

- Unceasing customer service

Track the below URL for one-step submission https://juniperpublishers.com/online-submission.php 